\title{
UJI REPELLENT DAN ATRAKTAN EKSTRAK CALOTROPIS GIGANTEA DENGAN DUA JENIS EKSTRAKSI TANAMAN TERHADAP KEONG MAS (Pomacea Cannaliculata)
}

\author{
Repellent Test And Galantea Extract Calotropis Extract With Two Types Of Plant Extraction \\ To Mas Conch (Pomacea Cannaliculata)
}

\author{
Dian Ekawati Sari ${ }^{1)}$, Bakhtiar $^{2)}$, Dian Yustisia ${ }^{3)}$, Mawar $^{4)}$ \\ Email:dianekawatisari@rocketmail.com
}

\author{
Sekolah Tinggi Ilmu Pertanian Muhammadiyah Sinjai ${ }^{134)}$ \\ Balai Proteksi Tanaman Pangan dan Hortikultura Sulawesi Selatan ${ }^{2)}$
}

\begin{abstract}
Abstrak
Pomacea canaliculata menjadi salah satu organisme penganggu tanaman yang sangat meresahkan petani karena dapat menghambat produktivitas tanaman padi. Tindakan pengendalian P. canaliculata pada saat ini hanya bergantung pada pestisida sintetik dan pengendalian mekanik. Oleh karena itu, diperlukan upaya penanggulangan alternatif untuk mengendalikan hama tersebut dengan cara memanfaatkan ekstrak bahan alami tanaman yang lebih ramah lingkungan. Penelitian ini bertujuan untuk mengetahui efek repellent dan atraktan ekstrak C. gigantea terhadap hama P. canaliculata. Hasil penelitian menunjukkan bahwa C. gigantea memiliki sifat repellent dan atraktan berdasarkan ekstraksinya. Perlakuan dengan crude ekstrak/ekstrak kasar bersifat repellent terhadap P. canaliculata sedangkan Ekstrak segar dan daun utuh C. gigantea bersifat atraktan terhadap P. canaliculata.
\end{abstract}

Kata Kunci: P. canaliculata, C. gigantea, Repellent, Atraktan

\section{Abstract}

Pomacea canaliculata is one of the plant disturbing organisms that is very unsettling for farmers because it can inhibit the productivity of rice. Current control measures for P. canaliculata depend only on synthetic pesticides and mechanical control. Therefore, alternative coping efforts are needed to control these pests by utilizing natural plant extracts that are more environmentally friendly. This study aims to determine the effect of repellent and attractant extract of $C$. gigantea on $P$. canaliculata pests. The results showed that $C$. gigantea had repellent properties and attractants based on their extraction. Treatment with crude extracts / crude extracts is repellent to $P$. canaliculata while fresh extracts and whole leaves of $C$. gigantea are attractive to $P$. canaliculata.

Keywords: P. canaliculata, C. gigantea, Repellent, attractant

\section{PENDAHULUAN}

Pomacea canaliculata merupakan hama utama tanaman padi di Sulawesi Selatan yang mampu menyebabkan penurunan produksi. $P$. canaliculata menyerang tanaman padi mulai persemaian sampai fase vegetative tanaman padi. P. canaliculata menyerang tanaman dengan cara memotong tanaman muda dan pada umumnya tanaman yang telah diserang oleh P. canaliculata tidak dapat lagi melanjutkan pertumbuhannya. Gejala yang ditimbulkan $P$. canaliculata sangat mempengaruhi produksi sehingga diperlukan adanya tindakan pengendalian. Tindakan pengendalian yang telah banyak dilakukan oleh petani pada saat ini yaitu penggunaan pestisida sintetik. Penggunaan pestisida dikalangan petani cenderung berlebihan sehingga dalam jangka waktu 
yang lama dapat berdampak negatif pada lingkungan dan organisme lainnya. Oleh karena itu, diperlukan alternatif lain untuk mengendalikan $P$. canaliculata dengan cara memanfaatkan tanaman liar yang belum banyak diketahui oleh masyarakat sehingga pengendalian tersebut menjadi ramah lingkungan.

C. gigantea berpotensi dalam mengendalikan hama dan mikroba. Getah tanaman C. gigantea terbukti efektif terhadap mortalitas $P$. canaliculata pada konsentrasi $0.06 \mathrm{ml} / \mathrm{ml}$ (Mayasari, 2016). Pada penelitian yang telah dilakukan oleh Shahabuddin dan Pasaru (2009) mengatakan bahwa ekstrak $C$. gigantea memiliki aktivitas penghambatan pertumbuhan $50 \%$ terhadap larva Spodoptera exigua. Selain untuk serangga dan moluska, $C$. gigantea juga memiliki aktivitas antibacterial (Kumar et al., 2010), antifungal (Saratha and Subramanian, 2010) dan dapat menekan pertumbuhan patogen tananaman padi (Viji et al., 2013). Ekstrak C. gigantea memiliki toxin seperti cardenolides, glikosida cardiac, flavonoid, dan cytotoxin. Sehubungan dengan hal diatas maka penelitian ini bertujuan untuk mengetahui efek tanaman $C$. gigantea terhadap $P$. canaliculata.

\section{METODE PENELITIAN}

Tempat dan Waktu

Penelitian dilaksanakan di Desa Tombolo Kec. Gantarangkeke Kabupaten
Bantaeng. Penelitian berlangsung mulai Juni sampai Agustus 2019.

Persiapan serangga uji

Pengumpulan dan Adaptasi P. canaliculata

P. canaliculata dikumpulkan dari areal pertanaman untuk dilakukan proses adaptasi. Perbanyakan bertujuan agar memperoleh $P$. canaliculata dalam keadaan segar sebagai bahan pengujian.

\section{Pembuatan ekstrak tanaman}

Ekstraksi tanaman menggunakan pelarut metanol teknis bertujun untuk memperoleh ekstrak kasar (crude extract) dari tanaman tersebut. Bagian tanaman tersebut dipotong-potong kecil lalu direndam dengan larutan metanol teknis. Setelah 7 hari perendaman, ekstrak disaring dan larutannya dimasukkan ke dalam water bath untuk menguapkan metanol teknis. Ekstrak segar didapatkan dengan cara tanaman dihaluskan dan ditambahkan air.

\section{Uji Atraktan dan Repellent}

Pengujian atraktan atau repellent dilakukan dengan cara pemilihan beberapa objek, Sebanyak 50 keong diinfestasikan ke dalam pertanaman buatan. Perlakuan terdiri atas 7 perlakuan setiap perlakuan diulang sebanyak 4 kali. Adapun perlakuaannya yaitu :

P0 : Kontrol

P1 : Crude ekstrak C. gigantea $3 \%$ 
P2 : Crude ekstrak C. gigantea $4 \%$

P3 : Crude ekstrak C. gigantea $5 \%$

P4 : Ekstrak segar C. gigantea $30 \%$

P5 : Ekstrak segar C. gigantea $60 \%$

P6 : Ekstrak segar C. gigantea $90 \%$

P7 : Daun C. gigantea

\section{Analisis Data}

Rancangan yang digunakan dalam penelitian adalah rancangan acak lengkap (RAL) yang terkumpul dianalisis menggunakan analisis varian. Jika ada pengaruh maka dilanjutkan dengan uji BNT.

\section{HASIL}

Hasil pengamatan terhadap populasi $P$. canaliculata setiap perlakuan disajikan pada Tabel di bawah ini. Pada Tabel 1 memperlihatkan rata-rata populasi $P$. canaliculata disetiap jam pengamatan. Ekstrak yang memperlihatkan adanya sifat ketertarikan oleh $P$. canaliculata yaitu pada ekstrak segar dan daun C. gigantea.

Tabel 1. Populasi P. canaliculata setiap perlakuan

\begin{tabular}{lcccc}
\hline \multirow{2}{*}{ Perlakuan } & \multicolumn{4}{c}{ Rata-rata populasi P.canaliculata $($ Jam) } \\
\cline { 2 - 5 } & $1 \mathrm{Jam}$ & $12 \mathrm{Jam}$ & 1 Hari & 2 Hari \\
\hline Kontrol & $1.25^{\mathrm{a}}$ & $1.00^{\mathrm{a}}$ & $1.5^{\mathrm{a}}$ & $1.25^{\mathrm{ab}}$ \\
Crude ekstrak 3\% & $0.00^{\mathrm{a}}$ & $0.00^{\mathrm{a}}$ & $0^{\mathrm{a}}$ & $0.25^{\mathrm{a}}$ \\
Crude ekstrak 4\% & $0.25^{\mathrm{a}}$ & $0.50^{\mathrm{a}}$ & $1.5^{\mathrm{a}}$ & $1.5^{\mathrm{ab}}$ \\
Crude ekstrak 5\% & $0.75^{\mathrm{a}}$ & $0.75^{\mathrm{a}}$ & $0.75^{\mathrm{a}}$ & $2^{\mathrm{ab}}$ \\
Ekstrak segar 30 \% & $3.00^{\mathrm{b}}$ & $2.00^{\mathrm{ab}}$ & $4^{\mathrm{b}}$ & $3^{\mathrm{b}}$ \\
Ekstrak segar 60 \% & $2.00^{\mathrm{b}}$ & $6.25^{\mathrm{c}}$ & $4.25^{\mathrm{b}}$ & $8^{\mathrm{d}}$ \\
Ekstrak segar 90 \% & $2.25^{\mathrm{b}}$ & $5.75^{\mathrm{c}}$ & $4.75^{\mathrm{b}}$ & $7.75^{\mathrm{d}}$ \\
Daun C. Gigantean & $0.75^{\mathrm{a}}$ & $4.00^{\mathrm{bc}}$ & $5.25^{\mathrm{b}}$ & $5.5^{\mathrm{c}}$ \\
\hline
\end{tabular}

Keterangan : Angka-angka yang diikuti dengan huruf yang sama pada kolom yang sama tidak berbeda nyata pada uji BNT 0.05.

Hasil analisis rata-rata populasi pada beberapa perlakuan pada Tabel 1 menunjukkan pada pengamatan 1 jam, 16 jam, 24 jam menunjukkan perlakuan crude ekstrak $3 \%, 4 \%, 5 \%$ dan daun $C$. gigantea tidak berbeda nyata dengan kontrol sedangkan pada perlakuan ekstrak segar $30 \%, 60 \%$ dan $90 \%$ berbeda nyata dengan kontrol namun tidak berbeda nyata antar perlakuan ekstrak segar. Pada pengamatan 2 hari setelah aplikasi perlakuan crude ekstrak $3 \%, 4 \%$, dan $5 \%$ tidak berbeda nyata dengan kontrol dan ekstrak segar $30 \%$ sedangkan daun $C$. gigantea berbeda nyata dengan semua perlakuan. Perlakuan ekstrak segar $60 \%$ dan $90 \%$ berbeda nyata dengan kontrol. 
Tabel 2. Efek repellent/atraktan ekstrak $C$. gigantea terhadap $P$. canaliculata

\begin{tabular}{lcl}
\hline Perlakuan & Nilai & Sifat \\
\hline Crude ekstrak 3\% & 0.95 & Repellent \\
Crude ekstrak $4 \%$ & 0.25 & Repellent \\
Crude ekstrak 5\% 5 Repellent \\
Ekstrak segar 30 \% & 0.15 & Atraktan \\
Ekstrak segar 60 \% & -1.40 & Atraktan \\
Ekstrak segar 90 \% & -3.10 & Atraktan \\
Daun C. gigantea & -3.15 & Atraktan \\
\hline
\end{tabular}

Pada tabel diatas menunjukkan bahwa ekstrak $C$. gigantea memiliki efek repellent dan atraktan. Hasil konversi menurut Pascual dan Robdelo (1998) menunjukkan jika hasil konversi bernilai positif maka bersifat repellent dan jika negatif maka bersifat atraktan. Pada Tabel 2 menunjukkan bahwa $C$. gigantea dengan crude ekstrak $3 \%, 4 \%$ dan $5 \%$ bersifat repellent dengan masing-masing sebesar 0.95, 0.25 dan 0,15. Ekstrak segar $C$. gigantea bersifat atraktan pada perlakuan ekstrak segar $30 \%, 60 \%, 90 \%$ dan daun C. gigantea dengan masing-masing sebesar -1.40, -3.10, -3.15 dan -2.10.

\section{PEMBAHASAN}

C. gigantea dengan ekstraksi methanol memiliki efek repellent terhadap $P$. canaliculata karena senyawa yang terkandung dalam ekstrak tersebut membuat $P$. canaliculata tidak memakan bibit tanaman padi pada penelitian ini. Senyawa yang terkandung dalam crude ekstrak/ekstrak kasar adalah senyawa metabolit sekunder yang telah diekstraksi tanpa adanya campuran senyawa primer tanaman. Senyawa-senyawa metabolit sekunder yang terkandung diantaranya cardenolides, cardiac glycosides, flavonoids, giganticine (Prabhu et al., 2012) tannin, saponin, steroid dan terpenoid (Seniya et al., 2011). Tanin yang terdapat dalam tanaman, mempunyai rasa sepat dan pada umumnya tanaman yang mempunyai kandungan tannin dihindari oleh herbivora. Senyawa lain yang bersifat penolak makan yang hanya dimiliki oleh tanaman tersebut yaitu senyawa giganticine. Penelitian yang dilakukan oleh Pari et al., (1998) mengatakan bahwa senyawa giganticine memiliki efek penolak makan terhadap nimfa Schistocerca gregaria. Ekstrak C. gigantea bersifat repellent terhadap hama Paraeucosmetus pallicornis (Sari, 2017). Daun $C$. gigantea mengandung alkaloid dan glikosida yang menyebabkan ekstrak daun widuri bersifat toksik terhadap serangga.

$P$. canaliculata tertarik pada ekstrak segar C. gigantea disebabkan oleh 
senyawa-senyawa primer yang terkandung dalam C. gigantea mampu menarik datangnya keong mas $C$. gigantea mempunyai kandungan protein yang tinggi. Witono (2008) daun dan pucuk $C$. gigantea mengandung pigmen klorofil yang terikat bersama protein. Selain itu, elite berperan sebagai filtrasi yang mampu menghilangkan protein dari suatu produk organic (Sharpe, 2005 dalam Witono, 2008). Hal diatas menunjukkan bahwa ekstrak segar $C$. gigantea memiliki kandungan protein walaupun telah diekstraksi segar sehingga keong mas tertarik untuk datang mendekat untuk memenuhi kebutuhannya. Kumar et.al. (2013) mengatakan bahwa $C$. gigantea kaya akan kandungan protein, asam amino, dan karbohidrat yang tersebar pada semua bagian tanaman.

\section{KESIMPULAN}

Hasil penelitian ini menyimpulkan bahwa $C$. gigantea memiliki efek repellent pada crude ekstrak/ekstrak kasar dengan pelarut methanol dan efek atraktan didapatkan pada ekstrak segar dan daun $C$. gigantea. Disarankan untuk melakukan pengujian lanjutan agar dapat diketahui keefektifannya terhadap $P$. canaliculata dilapangan.

\section{DAFTAR PUSTAKA}

Mayasari. S. L. 2016. Pemanfaatan Getah Biduri (Calotropis gigantea) dan Buah Lerak (Sapidus rarak) sebagai Pestisida Nabati Pembasmi Keong Mas (Pomacea canaliculata). Universitas Muhammadiyah Surakarta.

Kumar G, L. Karthik, K. V. B. Rao. 2010. Antibacterial activity of aqueous extract of Calotropis gigantea leaves - an in vitro study. International Journal of Pharmaceutical Sciences Review and Research Volume 4, Issue 2.

Kumar. P. S., E. Suresh and S. Kalavathy. 2013. Review on a Potential Herb Calotropis ggantea (L.) R. Br. Scholars Academic Journalof Fharmacy Vol. 2 No. 2.

Prabhu, S., P. Priyadharshini and R. Veeravel. 2012. Effect of Aqueous Extracts of Different Plant Parts of Milkweed Plant (Calotropis gigantea $\mathrm{R}$. Br.) against Ovicidal Activity on Helicoverpa armigera (Hubner). International Journal of Advanced Life Sciences (IJALS), Vol 2 Feb - April : 2012 ISSN $2277-758 X$.

Pari. K, P.J Rao, C. Devakumar, J.N Rastogi . 1998. A Novel Insect Antifeedant Nonprotein Amino Acid from Calotropis gigantean. Journal of Natural Products 61(1):102-4.

Saratha. V and S. P. Subramanian. (2010). Evaluation of antifungal activity of Calotropis gigantea latex extract: an in vitro study. International Journal of Pharmaceutical Sciences and Research Vol. 1 (9):88-96. 
Seniya. C, S. S. Trivedia, S. K. Verma. 2011. Antibacterial efficacy and Phytochemical analysis of organic solvent extracts of Calotropis gigantea. Journal of Chemical and Pharmaceutical Research 3(6):330336.

Shahabuddin dan F. Pasaru. (2009). Pengujian efek penghambatan ekstrak daun widuri terhadap pertumbuhan larva Spodoptera exigua Hubn. (Lepidoptera: Noctuidae) dengan menggunakan indeks pertumbuhan relative. $J$. Agroland 16 (2) : 148 - 154 .
Viji. R, P. Alaguraja, P. Mani. Velavan. (2013). Biological control of Calotropis gigantea leaf extracts against pathogenic fungus, infecting Oryza sativa. International Journal of Research in Pure and Applied Microbiology 3(4): 107-112.

Witono. Y. 2008. Deklorofilasi Ekstrak Protease dari Tanaman Biduri (Calotropis gigantean) dengan Absorban Celite. Berk. Penel. Hayati 13 (115-121). 